\title{
PENERAPAN REFORMASI KEHUMASAN DAN IMPLIKASINYA TERHADAP TINGKAT KEPATUHAN WAJIB PAJAK ORANG PRIBADI DALAM PELAPORAN SPT TAHUNAN SECARA E-FILING
}

\author{
Lufti Puji Setiadi \\ Direktorat Jenderal Pajak \\ Agus Bandiyono \\ Politeknik Keuangan Negara STAN \\ Alamat Korespondensi : agusbandiyono@pknstan.ac.id
}

\author{
INFORMASI ARTIKEL \\ Diterima Pertama \\ [15 Januari 2021] \\ Dinyatakan Diterima \\ [31 Maret 2021] \\ KATA KUNCl: \\ e-filling, SPT, reformasi kehumasan, kepatuhan WP, \\ perpajakan, keuangan Negara
}

KLASIFIKASI JEL:

\begin{abstract}
Taxation education is one of the duties of the Directorate General of Taxes as the tax administrator in Indonesia. The General Elucidation of Law Number 6 of 1983 concerning General Provisions and Tax Procedures as amended several times, most recently by UU Number 16 of 2009 states that tax administration duties include guidance, research, supervision and application of administrative sanctions. This study uses a descriptive type of research that compares the efiling of the annual tax return of personal taxpayers and the realization of tax education in 20182019. This research uses qualitative methods. The data used are interviews, document analysis, and literature study. Based on the results of the study, it was found that the contribution of the realization of tax education was directly proportional to the annual tax return of individual taxpayers for that year. To increase the annual tax return, the Bengkulu and Lampung Regional Tax Office made a new breakthrough and adjusted direct and indirect tax education. This is expected to help taxpayers understand the importance of taxation for the nation's development and increase taxpayer compliance.
\end{abstract}

Penyuluhan perpajakan merupakan salah satu tugas Direktorat Jenderal Pajak selaku administratur perpajakan di Indonesia. Penjelasan Umum Undang-Undang Nomor 6 Tahun 1983 tentang Ketentuan Umum dan Tata Cara Perpajakan sebagaimana telah beberapa kali diubah terakhir dengan Undang-Undang Nomor 16 Tahun 2009 menyatakan bahwa tugas administrasi perpajakan meliputi pembinaan, penelitian, pengawasan dan penerapan sanksi administrasi. Penelitian ini menggunakan jenis penelitian deskriptif yang membandingkan penerimaan SPT Tahunan Wajib Pajak Orang Pribadi secara efiling dan realisasi penyuluhan perpajakan tahun 2018-2019. Penelitian menggunakan metode kualitatif. Data yang digunakan yaitu wawancara, analisis dokumen, dan studi kepustakaan. Berdasarkan hasil penelitian didapat bahwa kontribusi realisasi penyuluhan perpajakan berbanding lurus dengan penerimaan SPT Tahunan Wajib Pajak Orang Pribadi pada tahun tersebut. Untuk meningkatkan penerimaan SPT Tahunan, Kanwil DJP Bengkulu dan Lampung melakukan terobosan baru dan menyesuaikan penyuluhan perpajakan secara langsung dan tidak langsung. Hal ini diharapkan dapat membantu Wajib Pajak memahami pentingnya perpajakan bagi perkembangan bangsa dan meningkatkan kepatuhan Wajib Pajak. 
pajak khususnya orang pribadi untuk melaporkan kewajiban perpajakan tahunannya yaitu melaporkan SPT Tahunan.

Terkait dengan ditetapkannya aturan ini, Pemerintah khususnya DJP ingin memudahkan masyarakat dalam hal pelaporan kewajiban perpajakannya sehingga tidak terikat waktu dan tempat. Di samping itu, e-filing juga memberikan dampak positif lainnya yaitu data perpajakan yang lebih terintegrasi dengan teknologi sehingga mengurangi pekerjaan penginputan kedalam sistem. Sehingga diharapkan melalui e-filing ini masyarakat menjadi lebih sadar akan kewajiban perpajakannya khususnya dalam hal pelaporan pajak.

Tujuan penelitian ini adalah untuk mengevaluasi penerapan reformasi kehumasan dan implikasinya terhadap tingkat kepatuhan wajib pajak orang pribadi di Kantor Wilayah DJP Bengkulu dan Lampung, menganalisis implikasi reformasi di bidang kehumasan, dalam hal penyuluhan perpajakan terhadap realisasi kepatuhan penerimaan SPT Tahunan secara EFilling pada Kantor Wilayah Direktorat Jenderal Pajak Bengkulu dan Lampung dan mengetahui hambatan-hambatan yang terjadi terkait pelaksanaan penyuluhan perpajakan di Kantor Wilayah Direktorat Jenderal Pajak Bengkulu dan Lampung.

\section{TINJAUAN PUSTAKA}

\section{Pengertian Wajib Pajak Orang Pribadi, SPT} Tahunan E-Filing dan Penyuluhan

Menurut Undang-Undang Nomor 6 Tahun 1983 sebagaimana telah diubah dengan UndangUndang Nomor 16 Tahun 2009 tentang Ketentuan Umum dan Tata Cara Perpajakan (KUP) yatu : "Wajib Pajak adalah orang pribadi atau badan, meliputi pembayar pajak, pemotong pajak, dan pemungut pajak, yang mempunyai hak dan kewajiban perpajakan sesuai dengan ketentuan peraturan perundang-undangan perpajakan.". Apabila mengacu pada peraturan perpajakan tersebut, pengertian Wajib Pajak adalah setiap orang yang terlibat dalam aktivitas perpajakan termasuk pembayar pajak, pemotong pajak, dan pemungut pajak.

Orang Pribadi sebagai subjek pajak dapat bertempat tinggal atau berada di Indonesia ataupun di luar Indonesia namun baru dikatakan sebagai Wajib Pajak Orang Pribadi ketika menerima dan/atau memperoleh penghasilan yang bersumber dari Indonesia atau menerima dan/atau memperoleh penghasilan yang bersumber dari Indonesia melalui bentuk usaha tetap di Indonesia. 
Menurut Undang-Undang Nomor 6 Tahun 1983 sebagaimana telah diubah dengan UndangUndang Nomor 16 Tahun 2009 tentang Ketentuan Umum dan Tata Cara Perpajakan (KUP) yaitu : "Surat Pemberitahuan adalah surat yang oleh Wajib Pajak digunakan untuk melaporkan penghitungan dan/atau pembayaran pajak, objek pajak dan/atau bukan objek pajak, dan/atau harta dan kewajiban sesuai dengan ketentuan peraturan perundang-undangan perpajakan". Sedangkan untuk pengertian SPT Tahunan berdasarkan UU KUP adalah adalah Surat Pemberitahuan untuk suatu tahun pajak atau bagian tahun pajak.

Efiling adalah suatu cara atau proses penyampaian SPT elektronik yang dilakukan secara online dan real time melalui koneksi jaringan internet pada website Direktorat Jenderal Pajak yang beralamat di www.pajak.go.id atau perusahaan Penyedia Jasa Aplikasi atau Application Service Provider (ASP). Keberadaan eFiling sendiri bertujuan untuk memudahkan Wajib Pajak pribadi dalam menunaikan kewajiban pelaporan pajak mereka.

Penyuluhan perpajakan merupakan salah satu tugas Direktorat Jenderal Pajak selaku administratur perpajakan di Indonesia. Penjelasan Umum Undang-Undang Nomor 6 Tahun 1983 tentang Ketentuan Umum dan Tata Cara Perpajakan sebagaimana telah beberapa kali diubah terakhir dengan Undang-Undang Nomor 16 Tahun 2009 menyatakan bahwa tugas administrasi perpajakan meliputi pembinaan, penelitian, pengawasan dan penerapan sanksi administrasi. Pembinaan masyarakat Wajib Pajak dapat dilakukan melalui berbagai upaya antara lain pemberian penyuluhan pengetahuan perpajakan. Untuk meningkatkan efektivitas pelaksanaan penyuluhan perpajakan agar menghasilkan perubahan pengetahuan, keterampilan, dan sikap, maka perlu disusun suatu metode penyuluhan yang terstruktur dan sistematis dalam bentuk pedoman pelaksanaan kegiatan penyuluhan perpajakan.

Surat Pemberitahuan Tahunan Wajib Pajak Orang Pribadi

Surat Pemberitahuan (SPT) adalah laporan pajak yang disampaikan kepada pemerintah Indonesia melalui Direktorat Jenderal Pajak (DJP). Kewajiban penyampaian SPT diatur dalam pasal 3 ayat 1 Undang-Undang Nomor 16 Tahun 2009 tentang Perubahan Keempat atas Undang-Undang Nomor 6 tahun 1983 tentang Ketentuan Umum dan Tata Cara Perpajakan (KUP) yang berbunyi: "Setiap Wajib Pajak wajib mengisi Surat Pemberitahuan dengan benar, lengkap, dan jelas, dalam bahasa Indonesia dengan menggunakan huruf Latin, angka Arab, satuan mata uang Rupiah, dan menandatangani serta menyampaikannya ke kantor Direktorat Jenderal Pajak tempat Wajib Pajak terdaftar atau dikukuhkan atau tempat lain yang ditetapkan oleh Direktur Jenderal Pajak."

SPT sendiri dibagi menjadi dua yakni SPT Masa dan SPT Tahunan. SPT Tahunan adalah surat pemberitahuan untuk suatu tahun pajak. Ini adalah jenis pelaporan pajak yang wajib dilakukan oleh Wajib Pajak Orang Pribadi maupun Wajib Pajak badan. Sedangkan SPT Masa adalah surat pemberitahuan untuk suatu masa pajak. SPT Masa digunakan untuk 10 jenis pajak yang telah ditetapkan oleh peraturan perpajakan.

Terdapat tiga kategori utama dari SPT Masa, yaitu Pajak Pertambahan Nilai (PPN), Pajak Penghasilan (PPh), dan Pajak Penjualan atas Barang Mewah (PPnBM). Untuk SPT Tahunan Wajib Pajak Orang Pribadi formulirnya dibagi menjadi beberapa bentuk sesuai jenis Wajib Pajaknya yaitu :

1. Formulir SPT Tahunan WP OP 1770 SS

2. Formulir SPT Tahunan WP OP $1770 \mathrm{~S}$

3. Formulir SPT Tahunan WP OP 1770

\section{E-Filling}

Berdasarkan Pasal 1 Peraturan Direktur Jenderal Pajak Nomor PER-1/PJ/2017, SPT Tahunan Elektronik adalah SPT Tahunan Pajak Penghasilan yang disampaikan dalam bentuk dokumen elektronik, baik berupa SPT Normal maupun SPT Pembetulan.

SPT Tahunan Elektronik wajib disampaikan oleh Wajib Pajak yang :

1. Diwajibkan menyampaikan SPT Masa Pajak Penghasilan Pasal 21 dalam bentuk dokumen elektronik sesuai dengan ketentuan peraturan perundang- undangan di bidang perpajakan dan memiliki kewajiban untuk melaporkan SPT Tahunan Pajak Penghasilan;

2. Diwajibkan menyampaikan SPT Masa Pajak Pertambahan Nilai dalam bentuk dokumen elektronik sesuai dengan ketentuan peraturan perundang-undangan di bidang perpajakan dan memiliki kewajiban untuk melaporkan SPT Tahunan Pajak Penghasilan;

3. Sudah pernah menyampaikan SPT Tahunan Elektronik;

4. Terdaftar di KPP Madya, KPP di lingkungan Kantor Wilayah Direktorat Jenderal Pajak Jakarta Khusus, dan KPP di lingkungan Kantor Wilayah Direktorat Jenderal Pajak Wajib Pajak Besar;

5. Menggunakan jasa konsultan pajak dalam pemenuhan kewajiban pengisian SPT Tahunan Pajak Penghasilan; dan/atau

6. Laporan keuangannya diaudit oleh akuntan publik. 
Wajib Pajak dapat menyampaikan SPT Elektronik ke KPP secara langsung, dikirim melalui pos/perusahaan jasa ekspedisi/kurir, atau dapat melalui saluran tertentu yang ditetapkan oleh Direktur Jenderal Pajak sesuai dengan perkembangan teknologi informasi, dalam hal ini adalah e-Filing.

E-filing adalah suatu cara atau proses penyampaian SPT elektronik yang dilakukan secara online dan real time melalui koneksi jaringan internet pada website Direktorat Jenderal Pajak yang beralamat di www.pajak.go.id atau perusahaan Penyedia Jasa Aplikasi atau Application Service Provider (ASP). Keberadaan eFiling sendiri bertujuan untuk memudahkan Wajib Pajak pribadi dalam menunaikan kewajiban pelaporan pajak mereka.

Dalam hal pelaporan SPT Tahunan via e-Filing, Selain mengisi formulir, Wajib Pajak juga diwajibkan untuk melampirkan keterangan dan/atau dokumen yang disyaratkan dalam SPT Elektronik sesuai dengan ketentuan peraturan perundang- undangan di bidang perpajakan. Namun terdapat pengecualian bagi Wajib Pajak Orang Pribadi yang menyampaikan SPT Tahunan Pajak Penghasilan 1770 S atau 1770 SS dengan status nihil atau kurang bayar melalui saluran tertentu (e-Filing) tidak diharuskan untuk menyampaikan atau mengunggah keterangan dan/atau dokumen yang disyaratkan sebagai berikut :

1. fotokopi Formulir 1721 A1/A2 atau bukti potong Pajak Penghasilan;

2. bukti pembayaran;

3. Surat Kuasa Khusus;

4. surat keterangan kematian;

5. penghitungan angsuran Pajak Penghasilan Pasal 25 tahun berikutnya;

6. perhitungan Pajak Penghasilan terutang bagi Wajib Pajak Kawin Pisah Harta dan/atau mempunyai NPWP sendiri; dan/atau

7. fotokopi bukti pembayaran zakat atau sumbangan keagamaan yang bersifat wajib.

Periode pelaporan SPT Tahunan Wajib Pajak Orang Pribadi dimulai sejak berakhirnya tahun pajak, sedangkan untuk batas waktu penyampaian SPT Tahunan Wajib Pajak Orang Pribadi mengikuti ketentuan batas waktu penyampaian SPT sesuai dengan ketentuan peraturan perundang-undangan di bidang perpajakan yaitu paling lama 3 bulan setelah batas akhir tahun pajak.

\section{Penyuluhan Perpajakan}

Penyuluhan perpajakan merupakan salah satu tugas Direktorat Jenderal Pajak selaku administratur perpajakan di Indonesia. Penjelasan Umum Undang-Undang Nomor 6 Tahun 1983 tentang Ketentuan Umum dan Tata Cara
Perpajakan sebagaimana telah beberapa kali diubah terakhir dengan Undang-Undang Nomor 16 Tahun 2009 menyatakan bahwa tugas administrasi perpajakan meliputi pembinaan, penelitian, pengawasan dan penerapan sanksi administrasi. Pembinaan masyarakat Wajib Pajak dapat dilakukan melalui berbagai upaya antara lain pemberian penyuluhan pengetahuan perpajakan. Untuk meningkatkan efektivitas pelaksanaan penyuluhan perpajakan agar menghasilkan perubahan pengetahuan, keterampilan, dan sikap, maka perlu disusun suatu metode penyuluhan yang terstruktur dan sistematis dalam bentuk pedoman pelaksanaan kegiatan penyuluhan perpajakan.

Berdasarkan Surat Edaran Direktur Jenderal Pajak Nomor SE-98/PJ/2011 tentang Pedoman Penyusunan Rencana Kerja dan Laporan Kegiatan Penyuluhan Perpajakan Unit Vertikal Direktorat Jenderal Pajak, bentuk pelaksanaan kegiatan penyuluhan yang dilakukan dapat berupa penyuluhan langsung dan tidak langsung.

Dalam melaksanakan penyuluhan perpajakan, setiap unit kerja di lingkungan Direktorat Jenderal Pajak agar mengikuti tahapan Manajemen Pelaksanaan Kegiatan Penyuluhan Perpajakan berdasarkan Surat Edaran Direktur Jenderal Pajak Nomor SE-05/PJ/2013 tentang Tata Cara Pelaksanaan Kegiatan Penyuluhan Perpajakan yang meliputi :

1. Perencanaan kegiatan

2. Pengorganisasian kegiatan

3. Pelaksanaan kegiatan

4. Pemantauan evaluasi dan pelaporan pelaksanaan kegiatan

\section{Reformasi Kehumasan}

Direktorat Jenderal Pajak (DJP) adalah salah satu Direktorat Jenderal di bawah Kementerian Keuangan yang mempunyai tugas merumuskan serta melaksanakan kebijakan dan standardisasi teknis di bidang perpajakan. DJP merupakan institusi penting di negeri ini di mana mayoritas pembiayaan APBN berasal dari penerimaan pajak. Pelayanan publik yang baik seharusnya dilaksanakan sesuai dengan kebutuhan masyarakat dan perubahan di berbagai sektor kehidupan berbangsa dan bernegara. Selain itu pelayanan publik harus diselenggarakan dengan tata kelola yang baik atau Good Governance (Agus, 2018). Sejak reformasi perpajakan yang dimulai pada tahun 2002, DJP telah melakukan banyak perubahan atau reformasi administrasi perpajakan. Dasar dari program ini adalah penerapan sistem administrasi perpajakan yang transparan dan akuntabel, dengan menggunakan teknologi informasi. Modernisasi ini pada hakikatnya adalah program reformasi birokrasi di 
Tim yang bertugas untuk pembuatan konten digital ini dinamakan Imagitaxion.

Reformasi Birokrasi Kemenkeu.

Presiden Republik Indonesia menetapkan Peraturan Presiden Nomor 81 Tahun 2010 tentang Grand Design Reformasi Birokrasi2010-2025 yang ditindaklanjuti dengan penerbitan Peraturan Menteri Pendayagunaan Aparatur Negara dan Reformasi Birokrasi Nomor 20 Tahun 2010 tentang Road Map Reformasi Birokrasi 2010-2014 dan Peraturan Menteri Pendayagunaan Aparatur Negara dan Reformasi Birokrasi Nomor 11 Tahun 2015 tentang Road Map Reformasi Birokrasi Tahun 2015 - 2019. Dengan adanya dukungan regulasi tersebut, gerakan Reformasi Birokrasi Kemenkeu bisa diintegrasikan dengan gerakan Reformasi Birokrasi Nasional.

Untuk memenuhi salah satu aspek yaitu sasaran reformasi birokrasi yaitu terwujudnya peningkatan kualitas pelayanan publik kepada masyarakat, maka Direktorat Jenderal Pajak pun turut serta melakukan reformasi dan pendekatan yang lebih baik kepada Wajib Pajak dan Calon Wajib Pajak. Pelayanan tersebut bukan hanya pelayanan yang bersifat menunggu Wajib Pajak datang namun juga mendatangi dan secara intensif memberikan informasi kepada Wajib Pajak melalui berbagai bentuk penyuluhan, baik langsung dan tidak langsung. Salah satu gerakan reformasi kehumasan yaitu membuat tim khusus pengelola media sosial dan tim khusus pembuat konten digital Direktorat Jenderal Pajak mengingat data yang dipublikasikan di Websindo.com (2019) pengguna aktif media sosial pada tahun 2019 berjumlah 150 juta yaitu 56\% dari total jumlah penduduk di Indonesia di mana $85 \%$ dari pengguna media sosial tersebut berusia di atas 18 tahun yang mana seharusnya sudah memiliki kewajiban perpajakan menurut Undang-Undang.

Tim pengelola media sosial resmi DJP disebut dengan Taxmin, yaitu tim yang dibentuk dari perwakilan tiap satuan kerja di lingkungan DJP yang memilik tugas adhoc dalam memberikan informasi dan merespons pertanyaan yang ditanyakan di sosial media. Media Sosial milik DJP pun terbagi menjadi akun resmi Nasional yang mana memberikan informasi terkait perpajakan secara keseluruhan dan juga akun wilayah milik satuan kerja wilayahnya masing-masing yang tugasnya menginformasikan kegiatam kegiatan perpajakan yang diadakan di wilayah kerjanya.

Berbeda dengan Taxmin, DJP juga memiliki tim pembuat konten digital dalam rangka edukasi masyarakat dengan cara yang menyenangkan. Konten-konten yang dibuat tetap berbobot namun lebih mudah dipahami oleh generasi milenial. Konten-konten tersebut bisa berupa infografis, short movie, animasi, iklan, komik dan lain-lain.

\section{METODE PENELITIAN}

Penelitian ini menggunakan metode penelitian deskriptif dengan pendekatan kualitatif yang akan membahas bagaimana merangkum sekumpulan data hasil penelitian, menganalisa dan disajikan dalam bentuk yang mudah dibaca serta dipahami. Teknik analisa data dimulai dari pengumpulan data, analisa data, penyajian data dan penarikan kesimpulan. Lokasi penelitian yaitu pada Kantor Wilayah Direktorat Jenderal Pajak Bengkulu dan Lampung yang beralamat di Jalan Pangeran Emir M. Noer Nomor 5A Kabupaten Sumur Putri, Kecamatan Teluk Betung Utara, Kota Bandar Lampung, Provinsi Lampung, satu gedung dengan Kantor Pelayanan Pajak Pratama Teluk Betung dan seksi penelitian dalam penelitian ini adalah seksi ekstensifikasi perpajakan dan bidang Penyuluhan Pelayanan dan Hubungan Masyarakat. Jenis data yang digunakan ada dua, yaitu data primer melalui wawancara dengan pegawai pajak yang berwenang terhadap realisasi penerimaan SPT Tahunan Wajib Pajak Orang Pribadi dan realisasi penyuluhan perpajakan serta data sekunder yang didapatkan dari dokumentasi dan studi kepustakaan.

\section{HASIL PENELITIAN DAN PEMBAHASAN}

Evaluasi Pelaksanaan Reformasi Kehumasan dalam Kegiatan Penyuluhan Perpajakan di Kanwil DJP Bengkulu dan Lampung

Dari hasil wawancara penulis dengan seorang pegawai bidang P2Humas Kanwil Direktorat Jenderal Pajak diketahui bahwa tatacara penyuluhan perpajakan Kanwil DJP Bengkulu dan Lampung telah dilakukan sesuai dengan prosedur yang seharusnya dan sesuai dengan ketentuan yang diatur dalam Surat Edaran Direktur Jenderal Pajak Nomor SE-05/PJ/2013 tentang Tata Cara Pelaksanaan Kegiatan Penyuluhan Perpajakan namun ada beberapa sedikit tambahan dalam pelaksanannya yaitu menambah metode POAC (Planning, Organizing, Actuating and Controlling).

Berdasarkan hasil wawancara salah satu pelaksana P2Humas Kanwil DJP Bengkulu dan Lampung, dalam melaksanakan fungsinya, Kanwil DJP juga rutin membentuk tim penyuluhan setiap awal tahun sesuai instruksi pada Surat Edaran Direktur Jenderal Pajak Nomor SE-99/PJ/2011 tentang Pedoman Pembentukan Tim Penyuluhan Perpajakan Unit Vertikal di Lingkungan Direktorat Jenderal Pajak dimana tim tersebut memiliki fokus 
yang dilakukan oleh P2Humas Kanwil DJP Bengkulu dan Lampung dalam rangka mendukung pelaksanaan tugas dan fungsi Kanwil kepada KPP dalam perencanaan dan pencapaian target seperti Forum bersama PEP dan P2Humas, Koordinasi dan bimbingan melalui email, telfon dan aplikasi Whatsapp, monitoring standar pelayanan satker vertikal, Penilaian Kantor Pelayanan Terbaik, Monitoring SPT Tahunan dan pembekalan Fasilitator Inklusi Pajak

Kontribusi Kegiatan Penyuluhan Perpajakan terhadap Penerimaan SPT Tahunan PPh Orang Pribadi secara efiling di Kanwil DJP Bengkulu dan Lampung

Menurut data yang didapat dari aplikasi Consolidated Report Data WareHouse Direktorat Jenderal Pajak terdapat kenaikan jumlah penerimaan SPT Tahunan PPh Wajib Pajak Orang Pribadi di Kanwil DJP Bengkulu dan Lampung dari tahun 2018 ke 2019 yaitu sebesar 49.917 SPT. Hal ini berbanding lurus dengan peningkatan realisasi kegiatan penyuluhan perpajakan yang digalakkan oleh Kanwil DJP Bengkulu dan Lampung yaitu sebesar 64,29\% lebih tinggi dibandingkan realisasinya tahun lalu. Untuk lebih jelasnya dapat dilihat pada tabel berikut :

Bengkulu dan Lampung, ada beberapa program

Tabel 1 Kenaikan Realisasi Penerimaan SPT Tahunan PPh Wajib Pajak Orang Pribadi secara efiling dari tahun 2018 ke 2019 di Kanwil DJP

Bengkulu dan Lampung

\begin{tabular}{|c|c|c|c|c|c|c|}
\hline & \multicolumn{2}{|c|}{2018} & \multicolumn{2}{|c|}{2019} & \multicolumn{2}{|c|}{$\begin{array}{l}\text { Kenaikan Realisasi Efiling } \\
\text { dari Tahun } 2018 \text { ke } 2019\end{array}$} \\
\hline & Angka & $\%$ & Angka & $\%$ & Angka & $\%$ \\
\hline $\begin{array}{l}\text { Realisasi Kegiatan } \\
\text { Penyuluhan } \\
\text { Perpajakan }\end{array}$ & 14 & $66,67 \%$ & 25 & $125 \%$ & 9 & $64,29 \%$ \\
\hline $\begin{array}{l}\text { Realisasi SPT } \\
\text { Tahunan WP OP } \\
\text { secara efiling } \\
\text { (Karyawan dan Non- } \\
\text { Karyawan) }\end{array}$ & 232.109 & $275,42 \%$ & 282.026 & $190,64 \%$ & 49.917 & $21,51 \%$ \\
\hline
\end{tabular}

Sumber: Aplikasi Consolidated Report Data WareHouse dan Aplikasi Penyuluhan Direktorat Jenderal Pajak

Dapat dilihat bahwa walau pun secara persentase realisasi penerimaan SPT Tahunan menurun dari $275,42 \%$ ke $190,64 \%$ namun secara angka SPT yang diterima mengalami kenaikan yang signifikan yaitu sebanyak 49.917 SPT Tahunan PPh Wajib Pajak Orang Pribadi yang disampaikan melalui efiling. Hal ini secara tidak langsung menyatakan bahwa hasil dari kegiatan ekstensifikasi berupa penyuluhan kepada Wajib
Pajak ini membuahkan hasil yang dapat dipetik dalam jangka panjang. Di mana Wajib Pajak yang diberikan sosialisasi oleh tenaga penyuluh khususnya terkait efiling dapat mengajak rekan kerja atau keluarga nya yang memiliki kewajiban dalam pelaporan SPT Tahunan untuk melakukan kewajiban perpajakannya dengan menggunakan efiling. Karena dengan adanya efiling ini sendiri, selain memudahkan Wajib Pajak dalam 
melaksanakan kewajiban pelaporannya karena dapat melakukan pelaporan di mana saja dan kapan saja selama terdapat koneksi jaringan internet, juga meningkatkan kualitas kelengkapan isi dari SPT Tahunan yang dilaporkan.

Berdasarkan hasil wawancara dengan salah satu pelaksana P2Humas Kanwil DJP Bengkulu dan Lampung, kegiatan penyuluhan perpajakan langsung seperti Workshop pengisian SPT Tahunan PPh Wajib Pajak Orang Pribadi secara efilling sangat diminati oleh Wajib Pajak khususnya para Wajib Pajak Badan dan Pemerintahan yang memiliki banyak pegawai yang diwajibkan untuk melaporkan SPT Tahunannya secara efiling. Biasanya, peserta yang datang ke workshop terkait pengisian SPT Tahunan PPh Wajib Pajak Orang Pribadi tersebut adalah Bendahara yang bertugas untuk memotong gaji pegawai dan memberikan bukti potong A1/A2 di kantor/unit kerjanya. Setelah menyelesaikan workshop tersebut, diharapkan peserta tersebut dapat membagikan ilmu yang didapat dari workshop tersebut kepada pegawai lain di unit kerjanya masing-masing. Selain kegiatan workshop, para mahasiswa dari Perguruan Tinggi juga menjadi sasaran P2Humas dalam pembentukan mindset untuk sadar akan kewajiban dan pentingnya perpajakan di Indonesia. Setiap tahun Kanwil selalu mengadakan kegiatan Tax Goes to Campus yang bertujuan untuk meningkatkan awareness anak-anak muda agar nanti ketika sudah memiliki kewajiban perpajakan, mereka akan taat dan patuh terhadap peraturan perpajakan yang berlaku.

\section{Hambatan-Hambatan yang Timbul dan Upaya Mengatasinya dalam Pelaksanaan Kegiatan Penyuluhan Perpajakan di Kanwil DJP Bengkulu dan Lampung}

Berdasarkan hasil wawancara dengan salah satu pelaksana P2Humas Kanwil DJP Bengkulu dan Lampung, terdapat beberapa hambatan dalam pelaksanaan penyuluhan perpajakan secara efektif yang diakibatkan oleh kondisi geografis wilayah kerja, infrastruktur, faktor-faktor eksternal seperti stigma/mindset Wajib Pajak dan juga sumber daya yang tersedia yang dapat digunakan dalam pelaksanaan penyuluhan perpajakan itu sendiri.

Dalam pelaksanaan kegiatan penyuluhan perpajakan, seringkali ada Wajib Pajak yang enggan untuk datang ke acara tersebut meskipun sudah diberikan undangan. Beberapa Wajib Pajak merasa takut terlebih dahulu dengan materi perpajakan yang akan disampaikan karena ketidaktahuan mereka dan paradigma yang mengatakan bahwa pajak itu menyeramkan. Padahal sudah banyak sekali sekarang sistem dan aplikasi bantuan untuk membantu dalam memahami kewajiban perpajakan, baik dalam perhitungan perpajakan maupun pemenuhan kewajiban lapor SPT. Informasi-informasi mengenai perpajakan pun sebenarnya sudah banyak tersedia di internet dengan berbagai bentuk mulai seperti video panduan dan lain-lain. Namun kembali lagi dikarenakan mindset yang tertanam pada Wajib Pajak bahwa pajak adalah sesuatu yang menyeramkan membuat mereka enggan untuk mencari tahu bahkan cenderung menjadi malas apabila tidak ada keperluan yang berkaitan dengan haknya. Hal ini tentu saja tidak ingin kita biarkan karena sejatinya perpajakan adalah suatu kewajiban dan bentuk kontribusi kita dalam pembangunan negara. Oleh sebab itu, hambatan tersebut idealnya dapat ditanggulangi dengan menghubungi Wajib Pajak secara langsung, bukan dengan Surat Undangan untuk mengajak mereka mengiikuti kegiatan penyuluhan perpajakan. Secara langsung di sini bukan berarti tim penyuluh harus bertatap muka dengan Wajib Pajak tersebut. Undangan juga dapat diberikan via telfon atau Whatsapp dengan tidak melupakan formalitas dan kesopanan. Dengan hal tersebut akan terasa ada kedekatan dan keakraban yang dapat dibangun antara pegawai pajak dan Wajib Pajak. Karena menurut pengakuan Wajib Pajak kepada narasumber, beberapa orang, ketika mendapatkan suatu surat dari DJP, akan langsung merasa ketakutan dan panik. Mereka merasa takut telah melakukan kesalahan karena tidak mengerti tentang perpajakan. Maka dari itu dibutuhkan pendekatan secara personal apalagi kepada Wajib Pajak yang berpotensi. Untuk jangka panjangnya, Kanwil DJP juga telah rutin melakukan kegiatan inklusi pajak di mana Kanwil bekerja sama dengan dinas pendidikan dan perguruan tinggi untuk menyusun kurikulum terkait materi perpajakan yang nantinya dapat dipelajari oleh anak-anak mulai dari jenjang Sekolah Dasar sampai Perguruan Tinggi. Hal ini akan lebih mengenalkan pajak kepada generasi muda dan nantinya akan menghapus stigma bahwa pajak itu sebenarnya tidak menakutkan dan mudah dipahami asal ada keinginan untuk mengenalnya lebih jauh.

Hambatan lainnya yaitu terkadang Wajib Pajak malas untuk datang pada kegiatan penyuluhan perpajakan yang diadakan dan memilih untuk melakukan kegiatan lain. Menurut narasumber, beberapa Wajib Pajak terkadang melakukan kewajiban perpajakan hanya ketika sedang membutuhkan bukti telah melakukan kewajiban tersebut untuk memenuhi syarat dalam mendapatkan sesuatu saja, misalnya pinjaman. Ketika sudah mendapatkan hal yang dibutuhkan, 
biasanya Wajib Pajak melupakan dan malas melakukan kewajiban rutinnya seperti SPT Tahunan PPh Orang Pribadi. Untuk mengurangi kemalasan tersebut Wajib Pajak, Kanwil DJP juga telah menyebarluaskan konten digital pada berbagai media sosial yang dimiliki oleh Kanwil DJP Bengkulu dan Lampung sehingga kapan pun dan dimana pun, Wajib Pajak dapat mengakses informasi terbaru terkait perpajakan dengan mudah. Selain itu, Kanwil DJP Bengkulu dan Lampung juga menggunakan fitur SMS Blast di mana Kanwil DJP Bengkulu dan Lampung bekerja sama dengan salah satu operator seluler mengirimkan pesan singkat atau Short Message Service (SMS) kepada pengguna provider di wilayah tersebut terkait informasi mengenai perpajakan. Fitur ini juga bisa digunakan untuk mengingatkan batas akhir pelaporan SPT Tahunan PPh Orang Pribadi sehingga tanpa mencari pun, Wajib Pajak masih bisa mendapatkan pemberitahuan tentang informasi perpajakan.

Selain Wajib Pajak itu sendiri, hambatan yang dihadapi oleh Bidang P2Humas dalam melakukan penyuluhan yaitu kendala kondisi geografis dan jarak tempuh unit kerja ke lokasi Wajib Pajak. Hambatan ini meliputi luas dan topografi wilayah, jarak antara unit kerja dengan Wajib Pajak yang berjauhan, sinyal dan koneksi internet yang tidak stabil atau bahkan tidak ada pada sebagian daerah terpencil di wilayah Bengkulu dan Lampung dan Sarana Prasarana untuk menjangkau wilayah terpencil yang kurang memadai seperti kendaraan dinas yang terbatas. Dengan segala keterbatasan tersebut, dilakukan upaya-upaya luar biasa untuk dapat menyampaikan informasi yang menjangkau sampai wilayah-wilayah terpencil tersebut.

Hambatan terakhir dalam kegiatan penyuluhan perpajakan yaitu terbatasnya tenaga penyuluh yang tersedia di Kanwil DJP maupun KPP tidak sebanding dengan Jumlah Wajib Pajak yang terdaftar dan luasnya wilayah yang meliputi dua provinsi yang cukup besar. Hal ini dikarenakan terdapat kualifikasi tertentu yang harus dipenuhi oleh seorang pegawai untuk diangkat menjadi tenaga penyuluh. Minimnya tenaga penyuluh membuat frekuensi penyuluhan tidak dapat dilakukan secara masif karena dibutuhkan perencanaan yang matang tiap kali melakukan suatu kegiatan penyuluhan perpajakan. Kemudian, beberapa tenaga penyuluh sudah memasuki usia yang tidak muda lagi sehigga kurang mampu secara efektik melakukan beban penyuluhan dengan frekuensi yang agak tinggi dan kondisi geografis yang terkadang ekstrim. Untuk menanggulangi masalah tersebut, bagian kepegawaian Kanwil DJP setiap tahunnya

$\begin{array}{lcc}\text { mengajukan nama-nama pegawai yang } \\ \text { berkualifikasi } & \text { untuk diikutikan } & \text { dalam }\end{array}$

diklat/workshop terkait penyuluhan perpajakan. Selain itu, untuk meringankan beban tenaga penyuluh juga dibuat konten digital tentang informasi perpajakan yang dapat diakses oleh Wajib Pajak selama tersedia jaringan internet, sehingga Wajib Pajak dapat teredukasi walaupun belum mendapatkan kesempatan untuk mengikuti kegiatan penyuluhan perpajakan oleh Kanwil DJP Bengkulu dan Lampung.

\section{SIMPULAN DAN SARAN}

\section{Kesimpulan}

Kegiatan penyuluhan mulai dari

Pembentukan Tim Penyuluhan Perpajakan, Perencanaan Penyuluhan Perpajakan dan Pelaksanaan Perencanaan penyuluhan perpajakan oleh Kantor Wilayah Direktorat Jenderal Pajak Bengkulu dan Lampung telah sesuai dengan standar aturan yang berlaku di Direktorat Jenderal Pajak. Dimulai dari pembentukan tim penyuluhan perpajakan yang sudah sesuai dengan yang disampaikan oleh Direktur Jenderal Pajak melalui Surat Edaran Nomor SE-99/PJ/2011 tentang Pedoman Pembentukan Tim Penyuluhan Perpajakan Unit Vertikal di Lingkungan Direktorat Jenderal Pajak meskipun dalam eksekusi di lapangan terjadi kendala-kendala baik dari faktor internal maupun eksternal Kanwil DJP Bengkulu dan Lampung.

Saran

Kanwil DJP Bengkulu dan Lampung hendaknya membuat suatu bentuk penyuluhan perpajakan yang interaktif dan menyenangkan, misalnya dengan menggunakan games atau perlombaan berhadiah yang mengaplikasikan nilai-nilai dan informasi terkait perpajakan. Akan lebih baik lagi apabila dalam satu kegiatan tersebut diadakan berbagai macam event yang dapat dinikmati oleh berbagai macam kalangan, dari anak-anak hingga dewasa. Hal ini selain untuk meningkatkan animo masyarakat dalam mengikuti penyuluhan perpajakan juga dapat secara perlahan mengubah stigma yang beredar di masyarakat bahwa pajak tidaklah menakutkan dan menyenangkan untuk dipahami.

\section{DAFTAR PUSTAKA}

Bandiyono, Agus. (2016). "Kualitas Pelayanan Institusi, Infrastruktur, Kesehatan dan Pendidikan serta Kepatuhan Pajak." Jurnal Kebijakan Publik 1-98. 
Bandiyono, Agus. (2018). "Penerapan Pelayanan Publik di Kantor Pelayanan Pajak." Jurnal Demokrasi dan Otonomi Daerah 1-80.

Khasanah, Septiani Nur. (2016). "Pengaruh Pengetahuan Perpajakan, Modernisasi Sistem Administrasi Perpajakan, Dan Kesadaran Wajib Pajak Terhadap Kepatuhan Wajib Pajak Pada Kantor Wilayah Direktorat Jenderal Pajak Daerah Istimewa Yogyakarta Tahun 2013." Jurnal Ilmiah Profita.

Nuraida, Afiah (2018). "Pengaruh Sosialiasi Perpajakan terhadap Kesadaran Peserta Didik dengan Program Tax Goes to School sebagai variabel moderating." Jurnal Ekobis Dewantara 0106.

Putra, Gilang Kumari. (2018). “Strategi Komunikasi Humas Ditjen Pajak RI Dalam Upaya Pemulihan Citra Pasca Kasus Gayus." Jurnal IImiah WIDYA 35-39.

Rohmawati, Alifa Nur., dkk (2012). "Pengaruh Kesadaran, Penyuluhan, Pelayanan, dan Sanksi Perpajakan pada Kepatuhan Wajib Pajak Orang Pribadi." Jurnal Ilmiah. Denpasar: Fakultas Ekonomi Universitas Udayana.

Warouw, Jounica Zsezsa Sabhatini., dkk. (2015). "Pengaruh Sosialisasi Perpajakan Terhadap Kepatuhan Pelaporan Spt Tahunan Wajib Pajak Badan." Jurnal Emba 585-592.

Mardiasmo. 2018. Perpajakan Edisi Terbaru 2018. Yogyakarta: Andi

Undang-Undang Nomor 6 Tahun 1983 tentang Ketentuan Umum dan Tata Cara Perpajakan sebagaimana telah beberapa kali diubah terakhir dengan Undang-Undang Nomor 28 Tahun 2007

Peraturan Menteri Keuangan Republik Indonesia Nomor 206.2/PMK.01/2014 tentang Perubahan Atas Peraturan Menteri Keuangan Nomor 167/PMK.01/2012 tentang Organisasi Dan Tata Kerja Instansi Vertikal Direktorat Jenderal Pajak

Peraturan Direktur Jenderal Pajak Nomor PER 01/PJ/2017 tentang Penyampaian Surat Pemberitahuan Elektronik

Peraturan Direktur Jenderal Pajak Nomor PER30/PJ/2017 tentang Perubahan Keempat atas Peraturan Direktur Jenderal Pajak Nomor PER-34/PJ/2010 tentang Bentuk Formulir Surat Pemberitahuan Tahunan Pajak Penghasilan Wajib Pajak Orang Pribadi

Peraturan Direktur Jenderal Pajak Nomor PER03/PJ/2013 tentang Pedoman Penyuluhan Perpajakan

Surat Edaran Direktur Jenderal Pajak Nomor SE05/PJ/2013 tentang Tata Cara Pelaksanaan Kegiatan Penyuluhan Perpajakan

Surat Edaran Direktur Jenderal Pajak Nomor SE98/PJ/2011 Tentang Pedoman Penyusuan Rencana Kerja dan Laporan Kegiatan Penyuluhan Perpajakan Unit Vertikal di Lingkungan Direktorat Jenderal Pajak

Surat Edaran Direktur Jenderal Pajak Nomor SE99/PJ/2011 Tentang Pedoman Pedoman Pembentukan Tim Penyuluhan Perpajakan Unit Vertikal di Lingkungan Direktorat Jenderal Pajak 